\title{
Bioequivalence of a Novel Omalizumab Solution for Injection Compared with the Standard Lyophilized Powder Formulation
}

Gilles J. Rivière ${ }^{1}$, Ching-Ming Yeh ${ }^{2}$, Christine V. Reynolds ${ }^{2}$, Laurence Brookman ${ }^{3}$ and Guenther Kaiser ${ }^{1 *}$

${ }^{1}$ Novartis Pharma AG, Basel, Switzerland

${ }^{2}$ Novartis Pharmaceuticals Corp., East Hanover, NJ, US

${ }^{3}$ Novartis Horsham Research Centre, Horsham, West Sussex, UK

\begin{abstract}
Aim: To determine the pharmacokinetic (PK) and pharmacodynamic (PD) comparability of a novel solution for injection (solution) and the reference lyophilized powder formulation (powder) of omalizumab.

Methods: In this open-label, parallel-group study, adult atopic subjects (serum immunoglobulin [Ig] E 30-300 IU/ $\mathrm{ml}$; body weight, $40-90 \mathrm{~kg}$ ) received a single subcutaneous dose (150 or $300 \mathrm{mg}$ ) of solution or powder omalizumab. Serum concentrations of total omalizumab, free and total $\lg E$ and safety were determined up to 84 days post dose. Bioequivalence was examined for dose-normalized parameters of omalizumab in serum: maximum concentration $\left(C_{\text {max }}\right)$, area under the concentration-time curve up to the last quantifiable concentration $\left(A \cup C_{0 \text {-tlast }}\right)$ and up to infinity $\left(A \cup C_{0 \text {-inf }}\right)$. Bioequivalence was concluded if the $90 \%$ confidence interval $(\mathrm{Cl})$ of the ratio of solution vs. powder geometric means was entirely contained within $0.8-1.25$.

Results: 155 subjects were randomized and dosed (62.6\% female; mean age, 34.7 years). Systemic exposure to omalizumab was similar for the two formulations at both doses. PK bioequivalence was demonstrated $(n=153)$ : $\mathrm{C}_{\max }$, ratio of geometric means: 1.01 (90\% Cl: 0.95-1.08); $\mathrm{AUC}_{\text {0-tast }}, 0.98(0.92-1.05) ; \mathrm{AUC}_{0 \text {-inf }} 0.98(0.91-1.05)$. Omalizumab mean elimination half-life: 22.1 days for solution; 22.9 days for powder. PD parameters $(n=154)$ of free and total $\mathrm{IgE}$ in serum were comparable between formulations; each produced a $95 \%$ reduction from screening in free lgE. Most common adverse events (AEs): headache (23.9\%), sinus congestion (8.4\%). No serious AEs were reported.
\end{abstract}

Conculsions: The novel, ready-to-use omalizumab solution formulation is bioequivalent to the reference lyophilized powder formulation.

Keywords: Allergic asthma; Bioequivalence; IgE; Lyophilized powder formulation; Omalizumab; Solution for injection

Abbreviations: AE: Adverse Event; ANOVA: Analysis of Vari-
ance; $\mathrm{AUC}_{0 \text {-inf }}$ : Area Under the Concentration-time curve up to infin-
ity; $\mathrm{AUC}_{0 \text {-tast }}$ Area Under the Concentration-time curve up to the last
quantifiable concentration; CI: Confidence Interval; CL/F: Apparent
total body clearance from serum; $\mathrm{C}_{\text {max }}$ : maximum concentration; CV\%:
Coefficient of Variation; ECG: Electrocardiograph; ELISA: Enzyme-
linked Immunosorbent Assay; Ig: Immunoglobulin; PD: Pharmacody-
namic; PK: Pharmacokinetic; SAE: Serious Adverse Event; SD: Stan-
dard Deviation; $\mathrm{t}_{1 / 2}$ : apparent terminal elimination half-life; $\mathrm{T}_{\text {max }}$ : time
to $\mathrm{C}_{\max } ; \mathrm{V}_{\mathrm{z}} / \mathrm{F}$ : apparent volume of distribution during terminal phase;
$\lambda_{\mathrm{z}}:$ apparent elimination rate constant estimated by linear regression
analysis of the terminal portion of the log-linear serum concentrationtime curve

\section{Introduction}

Immunoglobulin (Ig) E is a key mediator of allergic reactions, having a critical role in the induction and maintenance of chronic airway inflammation and asthma-related symptoms [1]. Allergic (IgEmediated) asthma is one of the most common chronic respiratory diseases, producing a variety of symptoms including cough, chest tightness, wheeze and difficulty in breathing [1-3]. Absence from work/ school, lost productivity and reduced quality of life associated with the disease imposes a significant burden on patients and society [4-7]. Omalizumab (XOLAIR ${ }^{\circledR}$, Novartis Pharma AG, Basel, Switzerland) is a recombinant DNA-derived humanized IgG monoclonal antibody that selectively binds to human IgE. Omalizumab has been approved as an add-on therapy in adults, adolescents and children ( $\geq 6$ years) for the treatment of IgE-mediated severe allergic asthma in the EU, and in adults and adolescents ( $\geq 12$ years) with moderate-to-severe allergic asthma in the U.S.

Omalizumab binds to circulating IgE, and thus inhibits mast cell and basophil activation by preventing the interaction of free $\operatorname{IgE}$ with its receptors. Consequently, the IgE receptor cells are disarmed and the initiation of the allergic cascade is prevented [8].

Omalizumab was first launched as a sterile, white, preservativefree, lyophilized powder in a single-use vial that has to be reconstituted with sterile water for injection (referred to as 'omalizumab powder for solution' hereafter). The powder for solution takes 15-20 min to dissolve because of the high protein concentration. The solution should be administered immediately after reconstitution. Chemical and physical stability of the reconstituted product have been demonstrated for $8 \mathrm{~h}$ if stored in the vial at $2-8^{\circ} \mathrm{C}$ and for $4 \mathrm{~h}$ if stored at $30^{\circ} \mathrm{C}$. In-

*Corresponding author: Guenther Kaiser PhD, Drug Metabolism \& Pharmacokinetics, Novartis Pharma AG, WSJ-210.4.20, CH-4002 Basel, Switzerland, Tel: +41 61 3248030; Fax: +41 61 3247167; E-mail: guenther kaiser@novartis.com

Received June 10, 2011; Accepted July 13, 2011; Published July 15, 2011

Citation: Rivière GJ, Yeh CM, Reynolds CV, Brookman L, Kaiser G (2011) Bioequivalence of a Novel Omalizumab Solution for Injection Compared with the Standard Lyophilized Powder Formulation. J Bioequiv Availab 3: 144-150. doi:10.4172/jbb.1000075

Copyright: (c) 2011 Rivière GJ, et al. This is an open-access article distributed under the terms of the Creative Commons Attribution License, which permits unrestricted use, distribution, and reproduction in any medium, provided the original author and source are credited. 
use storage times of the reconstituted product should not exceed these periods [9]. Hence, to provide a more convenient dosage form of the drug, a ready-to-use solution for injection (referred to as 'omalizumab solution' hereafter) was developed. The processes in manufacturing omalizumab solution and powder for solution are identical except for the final formulation step. Compared with the reconstituted omalizumab powder for solution, the drug concentration in the omalizumab solution formulation is increased from 125 to $150 \mathrm{mg} /$ $\mathrm{ml}$, resulting in a reduction of the injection volume by about $17 \%$, e.g., from 1.2 [9] to $1.0 \mathrm{ml}$ for a dose of $150 \mathrm{mg}$ omalizumab.

The current study was carried out to determine the pharmacokinetic (PK) and pharmacodynamic (PD) comparability of the new omalizumab solution with the reference omalizumab powder for solution after the administration of a single subcutaneous dose.

\section{Methods}

\section{Study design and population}

This was an open-label, randomized, two-parallel-group Phase III study conducted in four centers in the U.S. between November 2003 and August 2004.

Stable atopic male and female subjects (aged 18-65 years) with mild-to-moderate allergic asthma or allergic rhinitis, serum IgE levels of 30-300 IU/ml, body weight between 40 and $90 \mathrm{~kg}$, and who were otherwise in good health were eligible for enrolment in this study. Exclusion criteria included history of smoking, use of oral or parenteral corticosteroids, significant illness within the 2 weeks prior to the initiation of the study, and history of clinically significant drug allergy or previous monoclonal antibody therapy. Subjects with surgical or medical conditions that could have significantly altered the absorption, distribution, metabolism or excretion of any drug were also excluded. Those who entered the study were not allowed to start allergy vaccination therapy or take oral or parenteral corticosteroids at any point during the study. Concomitant use of inhaled corticosteroids and salbutamol as rescue medication was permitted.

The study was conducted in accordance with the International Conference on Harmonization Good Clinical Practice guidelines and the Declaration of Helsinki. Ethical approval for the trial was obtained from the institutional review boards of each participating study center, and written informed consent was received from all subjects included in the study.

\section{Study medication}

Omalizumab solution was supplied in vials containing $150 \mathrm{mg}$ of drug in a volume of $1.0 \mathrm{ml}$. The contents of the vial were drawn into a $3 \mathrm{ml}$ syringe fitted with a 26 gauge needle. Omalizumab powder for solution was supplied as a sterile, freeze-dried preparation, which was reconstituted with $1.4 \mathrm{ml}$ of sterile water for injection. After gentle swirling for approximately $1 \mathrm{~min}$, the vial was then swirled gently for 5-10 seconds every $5 \mathrm{~min}$ to dissolve any remaining solids, until no visible gel-like particles remained. The reconstituted powder for solution was then drawn into a $3 \mathrm{ml}$ syringe through an 18-gauge needle that was replaced with a 25 -gauge needle for subcutaneous administration. In order to obtain the required $1.2 \mathrm{ml}$ dose (which contains $150 \mathrm{mg}$ of omalizumab) any excess solution was expelled.

\section{Study visits and treatments}

The study included 15 outpatient visits: one baseline (screening) visit to confirm eligibility (Day-1), one visit for study drug administration (Day 1), and 13 visits from study Days 2 to 85 for PK and PD evaluations. After screening, subjects were assigned to one of 12 strata according to screening serum IgE level and body weight (Table 1). Subjects in each stratum were randomized to receive a single subcutaneous dose of either omalizumab solution or omalizumab powder for solution. Subjects received a single dose of either 150 or 300 $\mathrm{mg}$ as shown in Table 1. Dosing strata and doses were taken from the Xolair Summary of Product Characteristics [9].

\section{Drug administration and blood collection}

Both omalizumab formulations were administered into the deep subcutaneous tissue in the deltoid region of the right or left arm on Day 1. Blood samples for PK (total omalizumab) and PD (free and total $\operatorname{IgE}$ ) assessments were collected from each subject within $30 \mathrm{~min}$ prior to dosing and 6 and $12 \mathrm{~h}$ post-dose, after which the subjects were discharged from the study center. The subjects re-visited the study center for 13 additional PK and PD blood collection sessions on study Days 2, 3, 4, 6, 8, 11, 15, 22, 29, 43, 57, 71 and 85. Blood was allowed to clot for approximately $20 \mathrm{~min}$ and then centrifuged for $10 \mathrm{~min}$. Serum was removed and kept frozen at $\leq-18^{\circ} \mathrm{C}$ pending analysis. End-ofstudy evaluations were performed on Day 85 after collecting the last blood sample.

\section{Pharmacokinetic assessments}

Concentrations of total omalizumab (i.e., the sum of free omalizumab and omalizumab bound to IgE) in the serum samples were determined by a specific enzyme-linked immunosorbent assay (ELISA), as described previously [10]. The lower limit of quantification for total omalizumab was $16 \mathrm{ng} / \mathrm{ml}$, and the coefficients of variation for quality control samples ranged between $4.4 \%$ and $6.2 \%$. Serum concentration-time data were used to calculate the following PK parameters of omalizumab: maximum serum concentration $\left(\mathrm{C}_{\max }\right)$, time to $\mathrm{C}_{\max }\left(\mathrm{t}_{\max }\right)$, area under the serum concentration time curve from time 0 to the time of the last quantifiable concentration $\left(\mathrm{AUC}_{0 \text {-tlast }}\right)$, AUC from time 0 to infinity $\left(\mathrm{AUC}_{\text {0-inf }}\right)$, apparent terminal elimination half-life $\left(t_{1 / 2}\right)$, apparent total body clearance from serum $(\mathrm{CL} / \mathrm{F})$ and apparent volume of distribution during terminal phase $(\mathrm{V} / \mathrm{F})$. Calculations were performed in WinNonlin (Pharsight Corporation, Mountain View, CA) using non-compartmental methods and actual PK sampling times. $\mathrm{AUC}_{0 \text {-thast }}$ was calculated by the linear trapezoidal rule; $\mathrm{AUC}_{0 \text {-inf }}=\mathrm{AUC}_{0 \text {-tlast }}+\mathrm{C}_{\text {last }} / \lambda_{\mathrm{z}}$, where $\lambda_{\mathrm{z}}$ is the apparent elimination rate constant estimated by linear regression analysis of the terminal portion of the log-linear serum concentration-time curve; $t_{1 / 2}=\ln 2 / \lambda_{z}$; $\mathrm{CL} / \mathrm{F}=$ dose of omalizumab/AUC ${ }_{0 \text {-inf }}$, and $\mathrm{V}_{\mathrm{z}} / \mathrm{F}=\mathrm{CL} / \mathrm{F} / \lambda_{\mathrm{z}} \cdot \mathrm{C}_{\max }^{\mathrm{T} / 2}, \mathrm{AUC}_{0}$. tlast and $\mathrm{AUC}_{0 \text {-inf }}$ were also dose-normalized.

\section{Pharmacodynamic assessments}

Free IgE levels in the serum samples were determined by a previously reported specific ELISA [11], and total IgE levels (i.e., the sum of free and omalizumab-bound IgE) were determined by a micro-particle enzyme immunoassay test kit, commercially available from Abbot Inc., USA. For free IgE, the lower limit of quantification was $0.78 \mathrm{ng} / \mathrm{ml}$ and the upper limit was $150 \mathrm{ng} / \mathrm{ml}$. The coefficients of variation for quality control samples ranged between $2.8 \%$ and $9.3 \%$. For total IgE, the lower limit of quantification was $9.6 \mathrm{ng} / \mathrm{ml}$ and the coefficients of variation ranged between $6.9 \%$ and $11.1 \%$. Note that $1.0 \mathrm{IU} / \mathrm{ml} \mathrm{IgE}$ corresponds to $2.42 \mathrm{ng} / \mathrm{ml}$ IgE. The following PD parameters were determined for free IgE: minimum serum concentration $\left(\mathrm{C}_{\min }\right)$, time to $\mathrm{C}_{\min }\left(\mathrm{t}_{\min }\right)$ and maximum percentage decrease in serum free $\operatorname{IgE}$ concentration from screening ( $\max \%$ decrease). Parameters determined for total $\operatorname{IgE}$ 
Citation: Rivière GJ, Yeh CM, Reynolds CV, Brookman L, Kaiser G (2011) Bioequivalence of a Novel Omalizumab Solution for Injection Compared with the Standard Lyophilized Powder Formulation. J Bioequiv Availab 3: 144-150. doi:10.4172/jbb.1000075

were: $\mathrm{C}_{\max }, \mathrm{t}_{\max }$ and maximum percentage increase in serum total $\mathrm{IgE}$ concentration from screening (max \% increase).

\section{Safety and tolerability assessments}

Safety and tolerability assessments included: monitoring and recording of all adverse events (AEs) and serious adverse events (SAEs); regular checks of routine blood chemistry, hematology and urinalysis results; electrocardiographic (ECG) recordings; and physical examination and measurement of vital signs. Immunogenicity data for anti-omalizumab-Fab and anti-omalizumab-Fc fragments were determined by specific ELISAs in samples collected prior to the administration of omalizumab and on study Day 85 .

\section{Statistical analyses}

The PK and PD parameters were summarized using descriptive statistics (arithmetic mean and standard deviation [SD], median; range; coefficient of variation). All subjects with evaluable PK data were included in the PK data analysis, and the parameters were summarized per formulation and dose. Additionally, the PK parameters were pooled and summarized across the two doses of each formulation. PD parameters were summarized per formulation. All subjects who received treatment were included in the safety evaluation.

Inferential statistical analyses were performed on log-transformed dose-normalized PK parameters using an analysis of variance (ANOVA) model with stratum and formulation as factors. PK bioequivalence was examined for dose-normalized $\mathrm{C}_{\max }, \mathrm{AUC}_{0 \text {-tlast }}$ and $\mathrm{AUC}_{0 \text {-inf }}$ using the standard bioequivalence criterion of the $90 \%$ confidence interval (CI) of the ratio of the geometric means of the two formulations (omalizumab solution vs. powder for solution) being contained entirely within the range 0.8 to 1.25 . PD comparability was assessed using descriptive statistics and by visual inspection of the concentration-time curves of free and total IgE. No inferential analysis was performed on PD or safety data.

The sample size was selected to provide $80 \%$ power for the bioequivalence test. Assuming a coefficient of variation for $\mathrm{C}_{\max }$ and AUC of omalizumab of $40 \%$ as found in a previous study (Novartis, data on file) and a true ratio of the geometric means of 0.95 (or 1.05), the probability that the $90 \% \mathrm{CI}$ of the ratio falls into the range 0.80 to 1.25 is $80 \%$ for 65 subjects in each treatment group (omalizumab solution and omalizumab powder for solution). Thus, up to 160 subjects were to be enrolled to ensure that there were at least 65 evaluable subjects in each group at study completion.

\section{Results}

\section{Patient disposition and demographics}

A total of 155 subjects were randomized to study treatment, of whom 154 subjects (96 females and 58 males; 80 in the omalizumab powder for solution group and 74 in the omalizumab solution group; 104 at a dose of $150 \mathrm{mg}$ and 50 at a dose of $300 \mathrm{mg}$ ) completed the study; one subject in the omalizumab powder for solution group withdrew consent and did not complete the study. Omalizumab PK parameters were calculated for 153 subjects and were included in the statistical analyses for the comparison of the two formulations; one subject who received the omalizumab solution was excluded from the PK analysis due to uncertainty of dosing time (which did not allow calculation of the actual PK sampling times). Four subjects were administered a treatment that did not comply with the randomization schedule: two subjects incorrectly received the omalizumab solution for injection and two incorrectly received the powder for solution. Data were summarized and reported based on treatment received.

Demographics and baseline characteristics of the two treatment groups were similar (Table 2). Of 155 patients included in the study, $62.6 \%$ were female, $74.2 \%$ were Caucasian and the mean age was 34.7 years.

\section{Pharmacokinetic results}

PK data were available for 52 and 21 subjects who received the $150 \mathrm{mg}$ and $300 \mathrm{mg}$ dose, respectively, of omalizumab solution and for 52 and 28 subjects who received the $150 \mathrm{mg}$ and $300 \mathrm{mg}$ dose, respectively, of omalizumab powder for solution. The omalizumab solution and powder for solution formulations showed similar mean serum concentration-time profiles of omalizumab at each dose level (Figure 1). For both formulations, $\mathrm{C}_{\max }$ and $\mathrm{AUC}_{0 \text {-inf }}$ of omalizumab increased in proportion to the increase of dose, as shown in Figure 2. For instance, mean $\mathrm{C}_{\max }$ was $16,395 \mathrm{ng} / \mathrm{ml}$ and 32,230 ng/ml for $150 \mathrm{mg}$ and $300 \mathrm{mg}$, respectively, for omalizumab solution and was 15,907 ng/ $\mathrm{ml}$ and $32,571 \mathrm{ng} / \mathrm{ml}$, respectively, for omalizumab powder for solution. The mean CL/F was $258 \mathrm{ml} /$ day and $266 \mathrm{ml} /$ day for the two doses of the omalizumab solution and $251 \mathrm{ml} /$ day and $254 \mathrm{ml} /$ day for the respective doses of the omalizumab powder for solution. Consequently, dosenormalized parameters of $\mathrm{C}_{\max }, \mathrm{AUC}_{0 \text {-tlast }}$ and $\mathrm{AUC}_{0 \text {-inf }}$ were similar for the two doses of each formulation and all PK data (i.e. $\mathrm{C}_{\max } /$ dose, $\mathrm{AUC}_{0}$ tlast/dose and $\mathrm{AUC}_{0 \text {-inf }} /$ dose and the dose-independent parameters $\mathrm{t}_{\max }$. $\mathrm{t}_{1 / 2}, \mathrm{CL} / \mathrm{F}$ and $\mathrm{V}_{\mathrm{z}} / \mathrm{F}$ ) were pooled per formulation for the further analysis. Descriptive statistics (arithmetic mean \pm SD or median, range) for these pooled parameters are presented in Table 3.

The mean values of $\mathrm{C}_{\max } /$ dose, $\mathrm{AUC}_{0 \text {-tlast }} /$ dose and $\mathrm{AUC}_{0 \text {-inf }} /$ dose for the two formulations were similar. For example, mean $\mathrm{C}_{\max } /$ dose was $108.8 \mathrm{ng} / \mathrm{ml} / \mathrm{mg}$ for omalizumab solution compared with $106.9 \mathrm{ng} /$ $\mathrm{ml} / \mathrm{mg}$ for omalizumab powder for solution. Median $\mathrm{t}_{\max }$ was 5 days for both formulations. Values of $\mathrm{t}_{1 / 2}$ (22.1 vs. 22.9 days), CL/F (260 vs. $251 \mathrm{ml} /$ day $)$ and $\mathrm{V}_{\mathrm{z}} / \mathrm{F}(8.02$ vs. $8.11 \mathrm{l})$ were also similar between the formulations. Furthermore, inter-subject variability was similar for omalizumab solution and omalizumab powder for solution, as shown by the coefficient of variation values (Table 3 ). For the dose-normalized $\mathrm{C}_{\max }, \mathrm{AUC}_{0 \text {-tlast }}$ and $\mathrm{AUC}_{0 \text {-inf }}$ values, coefficient of variation ranged between $27.7 \%$ and $29.4 \%$ for the omalizumab solution and between $24.6 \%$ and $26.5 \%$ for the omalizumab powder for solution.

The statistical analysis of dose-normalized parameters $\mathrm{C}_{\max }, \mathrm{AUC}_{0}$ tlast and $\mathrm{AUC}_{0 \text {-inf }}$ gave the following results: the point estimate $(90 \% \mathrm{CI})$ of the ratio of the geometric means for the comparison of omalizumab solution versus powder for solution was $1.01(0.95-1.08)$ for $\mathrm{C}_{\max } / \mathrm{dose}$, 0.98 (0.92-1.05) for $\mathrm{AUC}_{0 \text {-tlast }} /$ dose and 0.98 (0.91-1.05) for $\mathrm{AUC}_{0 \text {-inf }}$ / dose. Thus, all CIs were confined within the pre-specified range of 0.80 to 1.25 required for demonstration of bioequivalence.

\section{Pharmacodynamic results}

PD data were available for 74 subjects who received the omalizumab solution and for 80 subjects who received the omalizumab powder for solution. After omalizumab administration, free IgE serum levels decreased rapidly whereas total IgE levels increased slowly (Figure 3 and Figure 4, respectively). Mean serum concentrations of free and total IgE were comparable between both formulations. The PD parameters are summarized in Table 4. For the omalizumab solution and powder for solution, respectively, mean $\mathrm{C}_{\min }$ of free IgE was $7.9 \mathrm{ng} /$ $\mathrm{ml}$ and $7.5 \mathrm{ng} / \mathrm{ml}$, corresponding to a mean maximum decrease of IgE 
Citation: Rivière GJ, Yeh CM, Reynolds CV, Brookman L, Kaiser G (2011) Bioequivalence of a Novel Omalizumab Solution for Injection Compared with the Standard Lyophilized Powder Formulation. J Bioequiv Availab 3: 144-150. doi:10.4172/jbb.1000075

from screening of $95.3 \%$ and $95.8 \%$. Median $t_{\text {min }}$ of free $\operatorname{IgE}$ was 2 days for both formulations, and median $\mathrm{t}_{\max }$ of total $\mathrm{IgE}$ was 21 days for both formulations.

\section{Safety}

No SAEs were reported during the study. There were 305 AEs reported by 77 subjects (omalizumab solution, $\mathrm{n}=33$; omalizumab powder for solution, $\mathrm{n}=44$ ). Of these AEs, 246 were rated as mild, 54 as moderate and five as severe. The severe AEs were upper respiratory tract infection, sinusitis, influenza, tooth injury and tympanic membrane perforation. None of the severe AEs were suspected of being related to omalizumab. Headache was the most commonly reported AE. Overall, 37 subjects (23.9\%) reported 81 events of headache, out of which 14 were considered to be study-drug related (11 mild and 3 moderate). AEs reported by more than four subjects in the overall study population are summarized in Table 5 . None of the subjects developed anti-omalizumab antibodies. There were no differences between the two groups with respect to changes in vital signs, ECG and biochemical parameters.

\section{Discussion}

Omalizumab is the first monoclonal antibody for the treatment of allergy-induced asthma, and its safety and efficacy has been established in clinical trials [12-16]. Omalizumab was first licensed as a stable lyophilized product (omalizumab powder for solution) to be administered as a subcutaneous injection for the treatment of patients with moderate-to-severe or severe persistent allergic (IgE-mediated) asthma. A novel omalizumab liquid formulation (omalizumab solution) for injection has been developed with the purpose of offering greater ease of administration and improved convenience. The reconstitution step of the omalizumab powder, which takes up to 20 min or longer in some cases [9], is not required for the omalizumab solution. This facilitates drug administration and eliminates a potential source of administration error, which could occur if the powder is incompletely dissolved or the injection volume deviates from the target volume (e.g. $1.2 \mathrm{ml}$ for a dose of $150 \mathrm{mg}$ ). In addition, for a given dose of omalizumab the injection volume is smaller for the omalizumab solution than for the powder for solution. In the present study, the PK and $\mathrm{PD}$ of the new omalizumab solution and the omalizumab powder for solution (reference formulation) were compared in subjects with elevated IgE levels.

Omalizumab exerts its pharmacological effect by binding to circulating IgE, whatever its allergen specificity, and prevents subsequent IgE-mediated responses. Binding of omalizumab to IgE reduces serum concentrations of free IgE and this reduction of serum free IgE is a surrogate marker of omalizumab efficacy [10,17]. The relationship between omalizumab and free IgE serum concentrations has been evaluated and described in various papers, using PK/PD modelling techniques $[10,17-19]$. From these evaluations, it is evident that in a given population, the two formulations of omalizumab would produce a comparable reduction of free IgE over a defined time period only if the omalizumab concentration-time profiles were also comparable. In our study, comparability of omalizumab PK was investigated by using a standard bioequivalence approach [20], i.e., by testing for equivalence of rate and extent of absorption of the drug into the systemic circulation after subcutaneous administration of single doses of the two formulations.

Bioequivalence studies are usually performed in healthy volunteers [20]. This population, however, would not have allowed investigation of the PD effect of omalizumab, i.e., the reduction of elevated IgE levels. Therefore, the population selected for our study were atopic subjects with mild-to-moderate asthma or allergic rhinitis and elevated serum IgE levels of 30 to $300 \mathrm{IU} / \mathrm{ml}$, who were otherwise in good health. In this population we could study the PD effect of omalizumab in addition to PK. The doses of omalizumab used in this study (150 mg or $300 \mathrm{mg}$ see Table 1) are in agreement with the therapeutic doses for patients with the body weight and baseline serum IgE characteristics of our study subjects. Patients with the specified body weights and baseline IgE levels who are eligible to be treated with omalizumab would receive either $150 \mathrm{mg}$ or $300 \mathrm{mg}$ omalizumab every 4 weeks [9].

\begin{tabular}{|l|l|l|l|l|l|}
\hline \multirow{2}{*}{ Screening IgE (IU/ml) } & Body weight $(\mathbf{k g})$ & \multicolumn{5}{l|}{} \\
\cline { 2 - 6 } & $>40-50$ & $>50-60$ & $>60-70$ & $>70-80$ & $>80-90$ \\
\hline $30-100$ & $150 \mathrm{mg}$ & $150 \mathrm{mg}$ & $150 \mathrm{mg}$ & $150 \mathrm{mg}$ & $150 \mathrm{mg}$ \\
\hline$>100-200$ & $300 \mathrm{mg}$ & $300 \mathrm{mg}$ & $300 \mathrm{mg}$ & $300 \mathrm{mg}$ & $300 \mathrm{mg}$ \\
\hline$>200-300$ & $300 \mathrm{mg}$ & $300 \mathrm{mg}$ & - & - & - \\
\hline
\end{tabular}

$\lg \mathrm{E}=$ immunoglobulin $\mathrm{E}$

Table 1: Omalizumab dosing strata.

\begin{tabular}{|c|c|c|c|}
\hline Demographic parameter & Omalizumab powder for solution & Omalizumab solution & Total \\
\hline No. of subjects, $n$ & 81 & 74 & 155 \\
\hline $\begin{array}{l}\text { Age (years), mean } \pm \text { SD } \\
\text { (range) }\end{array}$ & $\begin{array}{l}36.3 \pm 12.9 \\
(18-63)\end{array}$ & $\begin{array}{l}32.9 \pm 11.4 \\
(18-64)\end{array}$ & $\begin{array}{l}34.7 \pm 12.4 \\
(18-64)\end{array}$ \\
\hline $\begin{array}{l}\text { Weight }(\mathrm{kg}) \text {, mean } \pm \mathrm{SD} \\
\text { (range) }\end{array}$ & \begin{tabular}{|l|}
$70.8 \pm 11.8$ \\
$(47.4-90.0)$
\end{tabular} & \begin{tabular}{|l|}
$70.5 \pm 11.7$ \\
$(47.3-90.0)$ \\
\end{tabular} & $\begin{array}{l}70.6 \pm 11.7 \\
(47.3-90.0)\end{array}$ \\
\hline \multicolumn{4}{|l|}{ Gender, n (\%) } \\
\hline Male & $31(38.3)$ & $27(36.5)$ & $58(37.4)$ \\
\hline Female & $50(61.7)$ & $47(63.5)$ & $97(62.6)$ \\
\hline \multicolumn{4}{|l|}{ Race, n (\%) } \\
\hline Caucasians & $60(74.1)$ & $55(74.3)$ & $115(74.2)$ \\
\hline African-Americans & $9(11.1)$ & $10(13.5)$ & $19(12.3)$ \\
\hline Others & $12(14.8)$ & $9(12.2)$ & $21(13.5)$ \\
\hline
\end{tabular}

$\mathrm{SD}=$ standard deviation

Table 2: Patient demographics. 
Citation: Rivière GJ, Yeh CM, Reynolds CV, Brookman L, Kaiser G (2011) Bioequivalence of a Novel Omalizumab Solution for Injection Compared with the Standard Lyophilized Powder Formulation. J Bioequiv Availab 3: 144-150. doi:10.4172/jbb.1000075

\begin{tabular}{|c|c|c|c|c|c|c|c|c|}
\hline Formulation & Statistics & \begin{tabular}{|l|}
$C_{\text {max }} /$ dose \\
$(\mathrm{ng} / \mathrm{ml} / \mathrm{mg})$
\end{tabular} & $\begin{array}{l}t_{\max } \\
\text { (day) }\end{array}$ & $\begin{array}{l}\mathrm{AUC}_{\text {0-tlast }} / \mathrm{dose} \\
\text { (day· } \mu \mathrm{g} / \mathrm{ml} / \mathrm{mg} \text { ) }\end{array}$ & $\begin{array}{l}\text { AUC }_{0-\mathrm{inf}} / \mathrm{dose} \\
\text { (day. } \mu \mathrm{gg} / \mathrm{ml} / \mathrm{mg} \text { ) }\end{array}$ & $\begin{array}{l}t_{1 / 2} \\
\text { (day) }\end{array}$ & \begin{tabular}{|l} 
CL/F \\
(ml/day)
\end{tabular} & $\begin{array}{l}V_{2} / F \\
(I)\end{array}$ \\
\hline $\begin{array}{l}\text { Omalizumab } \\
\text { solution } \\
(n=73)\end{array}$ & $\begin{array}{l}\text { Mean } \pm \text { SD } \\
(\mathrm{CV} \%) \\
\text { Range }\end{array}$ & $\begin{array}{l}108.8 \pm 30.2 \\
(27.8) \\
48.0-176.9\end{array}$ & $\begin{array}{l}5.0^{\mathrm{a}} \\
- \\
2.0-14.0\end{array}$ & $\begin{array}{l}3.89 \pm 1.08 \\
(27.7) \\
1.44-6.37\end{array}$ & $\begin{array}{l}4.26 \pm 1.25 \\
(29.4) \\
1.50-7.33\end{array}$ & $\begin{array}{l}22.1 \pm 3.7 \\
(16.9) \\
14.8-31.6\end{array}$ & $\begin{array}{l}260 \pm 96 \\
(37.0) \\
136-667\end{array}$ & $\begin{array}{l}8.02 \pm 2.25 \\
(28.1) \\
4.69-17.48\end{array}$ \\
\hline $\begin{array}{l}\text { Omalizumab powder } \\
\text { for solution } \\
(n=80)\end{array}$ & $\begin{array}{l}\text { Mean } \pm \text { SD } \\
(\mathrm{CV} \%) \\
\text { Range }\end{array}$ & $\begin{array}{l}106.9 \pm 28.3 \\
(26.5) \\
41.5-175.7\end{array}$ & $\begin{array}{l}5.0^{\mathrm{a}} \\
- \\
1.0-14.0\end{array}$ & \begin{tabular}{|l|}
$.92 \pm 0.96$ \\
$(24.6)$ \\
$1.62-6.09$
\end{tabular} & \begin{tabular}{|l|}
$4.30 \pm 1.13$ \\
$(26.2)$ \\
$1.77-6.64$ \\
\end{tabular} & $\begin{array}{l}22.9 \pm 4.2 \\
(18.5) \\
15.3-34.2\end{array}$ & $\begin{array}{l}252 \pm 82 \\
(32.4) \\
151-565\end{array}$ & $\begin{array}{l}8.11 \pm 2.27 \\
(27.9) \\
5.10-18.81\end{array}$ \\
\hline
\end{tabular}

Median.

$\mathrm{C}_{\max }=$ maximum serum concentration, $\mathrm{t}_{\max }=$ time to $\mathrm{C}_{\max }, \mathrm{AUC}_{\text {- thast }}=$ area under the serum concentration time curve from time 0 to the time of the last quantifiable concentration, $\mathrm{AUC}_{0 \mathrm{if}}=\mathrm{AUC}$ from time 0 to infinity, $\mathrm{t}_{1 / \mathrm{s}}=$ apparent terminal elimination half-life, $\mathrm{CL} / \mathrm{F}=$ apparent total body clearance from serum, $\mathrm{V}_{z} / \mathrm{F}=$ apparent volume of distribution during terminal phase, $\mathrm{SD}=$ standard deviation, mean = arithmetic mean, $\mathrm{CV} \%=$ coefficient of variation.

Table 3: Pharmacokinetic parameters of omalizumab in serum after subcutaneous administration of omalizumab solution or omalizumab powder for solution

\begin{tabular}{|c|c|c|c|c|c|c|c|}
\hline \multirow[b]{2}{*}{ Formulation } & \multirow[b]{2}{*}{ Statistics } & \multicolumn{3}{|l|}{ Free $\lg E$} & \multicolumn{3}{|l|}{ Total IgE } \\
\hline & & $\begin{array}{l}\mathrm{C}_{\min } \\
(\mathrm{ng} / \mathrm{ml})\end{array}$ & $\begin{array}{l}\mathrm{t}_{\min } \\
\text { (day) }\end{array}$ & $\begin{array}{l}\text { Max \% decrease } \\
\text { from screening }\end{array}$ & $\begin{array}{l}\mathrm{C}_{\max } \\
(\mathrm{ng} / \mathrm{ml})\end{array}$ & $\begin{array}{l}\mathrm{t}_{\max } \\
\text { (day) }\end{array}$ & $\begin{array}{l}\text { Max \% increase } \\
\text { from screening }\end{array}$ \\
\hline $\begin{array}{l}\text { Omalizumab } \\
\text { solution } \\
(\mathrm{n}=74)\end{array}$ & $\begin{array}{l}\text { Mean } \pm \text { SD } \\
(\mathrm{CV} \%) \\
\text { Range }\end{array}$ & $\begin{array}{l}7.90 \pm 4.06 \\
(51.4) \\
1.00-21.30\end{array}$ & $\begin{array}{l}2.0^{a} \\
0.5-5.0\end{array}$ & $\begin{array}{l}95.3 \pm 3.0 \\
(3.1) \\
86.7-99.1\end{array}$ & $\begin{array}{l}1,176 \pm 723 \\
(61.5) \\
392-3,720\end{array}$ & $\begin{array}{l}21.0^{\mathrm{a}} \\
- \\
7.0-84.0\end{array}$ & $\begin{array}{l}490 \pm 172 \\
(35.2) \\
133-1,043\end{array}$ \\
\hline $\begin{array}{l}\text { Omalizumab powder } \\
\text { for solution } \\
(\mathrm{n}=80)\end{array}$ & $\begin{array}{l}\text { Mean } \pm \text { SD } \\
(\mathrm{CV} \%) \\
\text { Range }\end{array}$ & $\begin{array}{l}7.50 \pm 4.18 \\
(55.7) \\
1.95-21.30\end{array}$ & $\begin{array}{l}2.0^{\mathrm{a}} \\
- \\
0.5-28.0\end{array}$ & $\begin{array}{l}95.8 \pm 2.7 \\
(2.9) \\
85.0-99.3\end{array}$ & $\begin{array}{l}1,136 \pm 685 \\
(60.3) \\
144-3,612\end{array}$ & $\begin{array}{l}21.0^{\mathrm{a}} \\
10.0-84.0\end{array}$ & $\begin{array}{l}446 \pm 220 \\
(49.4) \\
39-1,452 \\
\end{array}$ \\
\hline
\end{tabular}

Median. standard deviation, $\mathrm{CV} \%=$ coefficient of variation.

Table 4: Pharmacodynamic parameters of free and total IgE in serum after subcutaneous administration of omalizumab solution and omalizumab powder for solution.

\begin{tabular}{|c|c|c|c|}
\hline Adverse events (preferred term) & $\begin{array}{l}\text { Omalizumab powder for solution }(n=81) \\
n(\%)\end{array}$ & $\begin{array}{l}\text { Omalizumab solution }(n=74) \\
n(\%)\end{array}$ & $\begin{array}{l}\text { Total } \\
(\mathrm{n}=155) \\
\mathrm{n}(\%)\end{array}$ \\
\hline Headache & $21(25.9)$ & $16(21.6)$ & $37(23.9)$ \\
\hline Sinus congestion & $6(7.4)$ & $7(9.5)$ & $13(8.4)$ \\
\hline Rhinorrhea & $4(4.9)$ & $7(9.5)$ & $11(7.1)$ \\
\hline Pharyngolaryngeal pain & $8(9.9)$ & $3(4.1)$ & $11(7.1)$ \\
\hline Sneezing & $5(6.2)$ & $3(4.1)$ & $8(5.2)$ \\
\hline Nausea & $5(6.2)$ & $3(4.1)$ & $8(5.2)$ \\
\hline Nasal congestion & $3(3.7)$ & $4(5.4)$ & $7(4.5)$ \\
\hline Vomiting & $3(3.7)$ & $2(2.7)$ & $5(3.2)$ \\
\hline Arthralgia & $4(4.9)$ & $1(1.4)$ & $5(3.2)$ \\
\hline Nasopharyngitis & $1(1.2)$ & $4(5.4)$ & $5(3.2)$ \\
\hline
\end{tabular}

Table 5: Most commonly reported adverse events ( $>4$ subjects in the overall study population).

Instead of the standard two-period, two-sequence crossover design which is normally used for the comparison of two formulations [20], we used a parallel-group design. This design was chosen since omalizumab has a very long half-life (averaged 26 days [9]) which would have required a washout period of about 6 months between treatments in a crossover study to allow omalizumab levels to drop below $1 \%$ of the peak concentration.

Since each formulation of omalizumab was given at two dose levels (150 $\mathrm{mg}$ and $300 \mathrm{mg}$ ), the first step of our PK analysis was a descriptive comparison between dose levels and between formulations at each dose level. This is illustrated in Figures 1 and 2. Systemic exposure to omalizumab increased dose-proportionally for each formulation and was similar for the two formulations at each dose level. Consequently, $\mathrm{C}_{\max }, \mathrm{AUC}_{0 \text {-tlast }}$ and $\mathrm{AUC}_{0 \text {-inf }}$ were dose-normalized and all PK data were pooled per formulation (Table 3 ). The statistical bioequivalence analysis using an ANOVA model demonstrated bioequivalence of omalizumab between the two omalizumab formulations. For all three PK parameters tested (i.e. $\mathrm{C}_{\max } /$ dose, $\mathrm{AUC}_{0 \text {-tlast }} /$ dose and $\mathrm{AUC}_{0 \text {-inf }} /$ dose) the $90 \% \mathrm{CI}$ of the treatment ratio was within the standard range $(0.8$ to 1.25 ) for concluding bioequivalence. The $90 \%$ CIs for these three parameters were even tighter (range 0.91 to 1.08 ) than the standard range. These tight $90 \%$ CIs reflect the relatively low inter-subject variability in omalizumab exposure observed in our study, as shown by coefficient of variation values of less than $30 \%$ for all PK parameters tested for bioequivalence.

The comparable rate of absorption of omalizumab from each formulation is further supported by the $t_{\max }$ values: the median was 5 days for each formulation. Disposition and elimination of omalizumab were also comparable between the formulations as shown by the respective mean $\mathrm{CL} / \mathrm{F}, \mathrm{V}_{\mathrm{z}} / \mathrm{F}$ and $\mathrm{t}_{1 / 2}$, values which were all close together (Table 3).

As discussed above, the PD marker for omalizumab efficacy is free IgE, and this study showed that the time course of serum free IgE after injection of omalizumab solution was superimposed on that after injection of the omalizumab powder for solution (Figure 3). Also, the maximum percentage decrease of free IgE from screening 
Citation: Rivière GJ, Yeh CM, Reynolds CV, Brookman L, Kaiser G (2011) Bioequivalence of a Novel Omalizumab Solution for Injection Compared with the Standard Lyophilized Powder Formulation. J Bioequiv Availab 3: 144-150. doi:10.4172/jbb.1000075

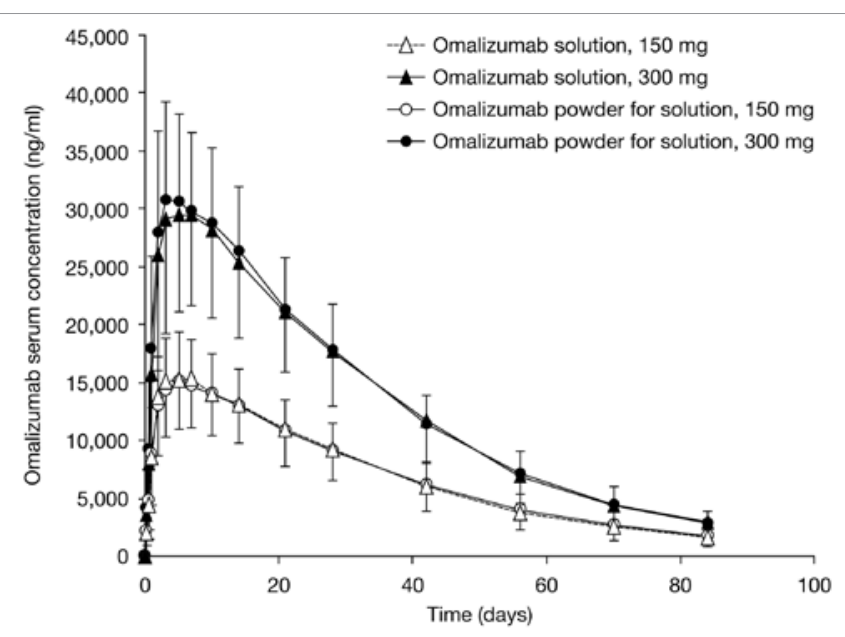

Figure 1: Arithmetic mean (+standard deviation [SD] for omalizumab powder for solution; -SD for omalizumab solution) omalizumab serum concentrationtime profiles by formulation and dose.

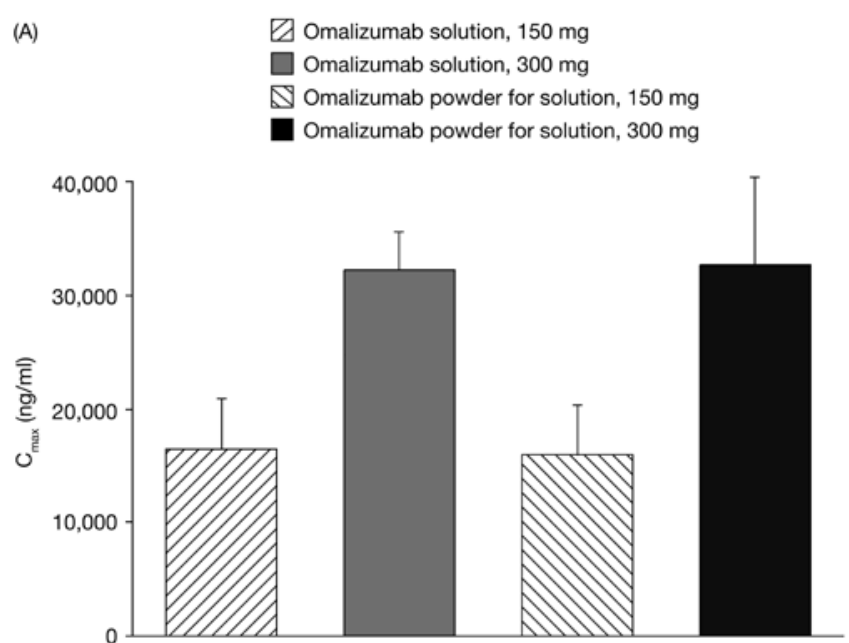

(B)
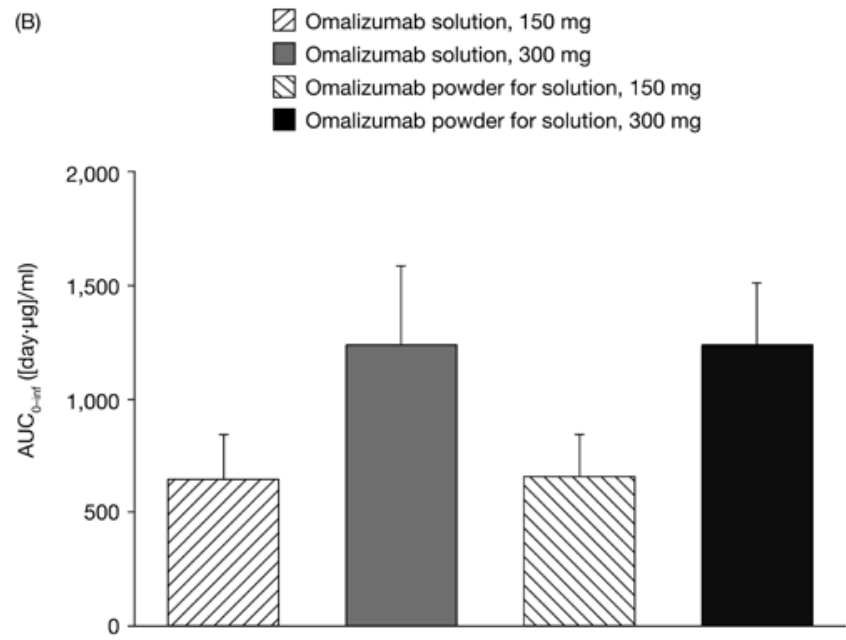

Figure 2: Arithmetic mean (+standard deviation) omalizumab maximum concentration $\left(C_{\text {max }}\right.$; panel $A$ ) and area under curve from time 0 to infinity $\left(A \cup C_{0-\text { inf }} ; \text { panel } B\right)^{\max }$.

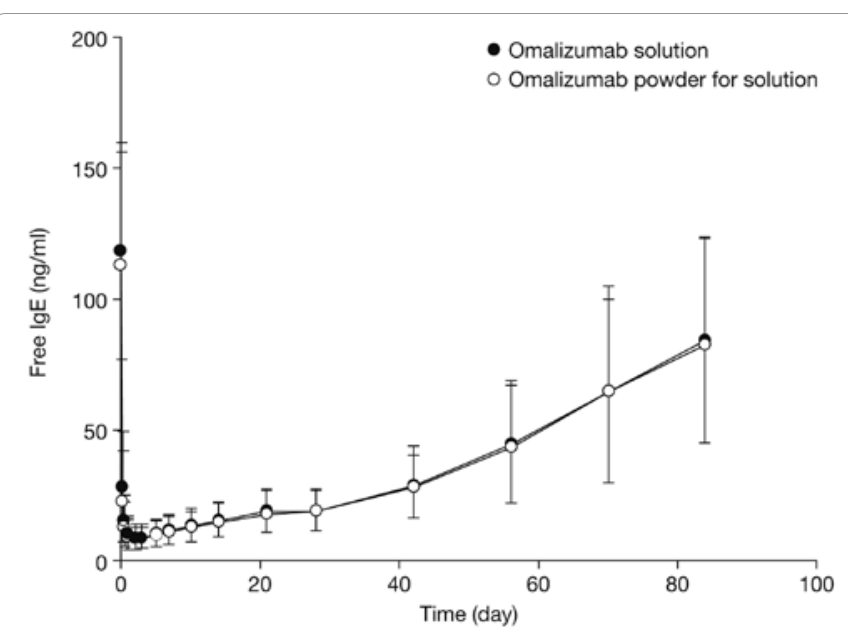

Figure 3: Arithmetic mean ( \pm standard deviation [SD]) serum concentrations of free immunoglobulin (lg) $E$ after subcutaneous administration of omalizumab solution and omalizumab powder for solution.

[Footnote] Due to assay limitations, the highest quantifiable free $\mathrm{lgE}$ concentration is $150 \mathrm{ng} / \mathrm{ml}$. All values higher than $150 \mathrm{ng} / \mathrm{ml}$ were considered as equal to $150 \mathrm{ng} / \mathrm{ml}$ for mean and SD calculations.

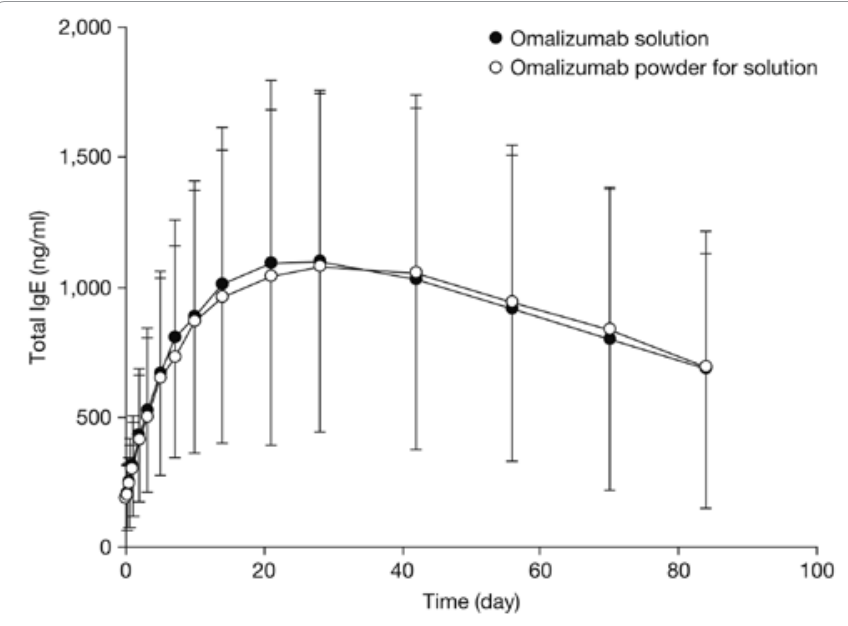

Figure 4: Arithmetic mean ( \pm standard deviation) serum concentrations of total immunoglobulin (lg) E after subcutaneous administration of omalizumab solution and omalizumab powder for solution.

was comparable (95.3\% vs. $95.8 \%$ ) between the formulations and was reached 2 days (median) after dosing.

Formation of complexes of IgE with omalizumab shifts $\operatorname{IgE}$ clearance from the relatively fast clearance of free $\operatorname{IgE}$ to the slower complex clearance $[18,21]$. This apparent reduction in IgE clearance, together with a redistribution of the ligand from extravascular sites into the systemic circulation [22], results in elevation in serum total IgE levels after omalizumab treatment. Thus, as a result of omalizumab binding to IgE, serum concentrations of free IgE are reduced, whereas concentrations of total IgE (i.e., the sum of free and omalizumab bound IgE) are increased. The latter is illustrated in Figure 4. Again, both formulations show very similar effects with a maximum increase reached 21 days (median) after dosing of each formulation.

The safety findings in this study were consistent with an earlier randomized, double-blind, dose-ranging, placebo-controlled trial 
Citation: Rivière GJ, Yeh CM, Reynolds CV, Brookman L, Kaiser G (2011) Bioequivalence of a Novel Omalizumab Solution for Injection Compared with the Standard Lyophilized Powder Formulation. J Bioequiv Availab 3: 144-150. doi:10.4172/jbb.1000075

that assessed the efficacy and safety of omalizumab administered prophylactically in patients with seasonal allergic rhinitis [23]. The safety results of that study revealed that headache, upper respiratory tract infection and viral infection were the most frequently reported AEs with omalizumab treatment; furthermore, the results showed that injection site reactions were mild and infrequent. In the current study, the most common AEs were headache and sinus congestion.

In conclusion, based on systemic exposure to omalizumab, our study demonstrated bioequivalence between the new omalizumab solution and the standard omalizumab powder for solution following single subcutaneous administration to subjects with elevated IgE levels. Additionally, both formulations produced a 95\% reduction in free $\operatorname{IgE}$ and had similar safety profiles. These data suggest that the omalizumab solution would be expected to provide efficacy and safety similar to that of the omalizumab powder for solution formulation.

\section{Acknowledgements}

Declaration of interest: This study was funded by Novartis Pharma AG, Basel, Switzerland. The authors thank Dr Alan Marion (MDS Pharma Services, Lincoln, Nebraska, US), Dr Irving Weston (MDS Pharma Services, Phoenix, Arizona, US), Dr Magdy Shenouda (MDS Pharma Services, Neptune, New Jersey, US), and Dr Ramon Vargas (MDS Pharma Services, New Orleans, Louisiana, US) for their participation in this study. Dr Sam T. Mathew and Dr Kaushik Sengupta (Document Operations in Clinical, Integrated Information Sciences and Informatics) assisted in the preparation of the manuscript. Helen Attisha (ACUMED), a professional medical writer funded by Novartis, and Gerald Dodson (Novartis) also assisted in the preparation of the manuscript.

\section{References}

1. Lemanske RF Jr, Busse WW (1997) Asthma. JAMA 278: 1855-1873.

2. Mullol J, Valero A, Alobid I, Bartra J, Navarro AM, et al. (2008) Allergic Rhinitis and its Impact on Asthma update (ARIA 2008). The perspective from Spain. J Investig Allergol Clin Immunol 18: 327-334.

3. Alyasin S, Amin R (2007) The evaluation of new classification of Allergic Rhinitis in patients referred to a clinic in the city of Shiraz. Iran J Allergy Asthma Immunol 6: 27-31.

4. Weiss KB, Gergen PJ, Hodgson TA (1992) An economic evaluation of asthma in the United States. N Engl J Med 326: 862-866.

5. Chen H, Blanc PD, Hayden ML, Bleecker ER, Chawla A, et al. (2008) Assessing productivity loss and activity impairment in severe or difficult-to-treat asthma. Value Health 11: 231-239.

6. Meng YY, Babey SH, Hastert TA, Lombardi C, Brown ER (2008) Uncontrolled asthma means missed work and school, emergency department visits for many Californians. Policy Brief UCLA Cent Health Policy Res (PB2008-2): 1-8.

7. Porsbjerg C, Rasmussen L, Nolte H, Backer V (2007) Association of airway hyperresponsiveness with reduced quality of life in patients with moderate to severe asthma. Ann Allergy Asthma Immunol 98: 44-50.

8. D'Amato G (2003) Therapy of allergic bronchial asthma with omalizumab - an anti-IgE monoclonal antibody. Expert Opin Biol Ther 3: 371-376.

9. Xolair [Summary of Product Characteristics] (2010) Novartis Europharm Limited, West Sussex, UK Available at http://www.medicines.org.uk/emc/ medicine/17029.

10. Lowe PJ, Tannenbaum S, Gautier A, Jimenez P (2009) Relationship between omalizumab pharmacokinetics, IgE pharmacodynamics and symptoms in patients with severe persistent allergic (IgE-mediated) asthma. $\mathrm{Br} \mathrm{J}$ Clin Pharmacol 68: 61-76.

11. Ädelroth E, Rak S, Haahtela T, Aasand G, Rosenhall L, et al. (2000) Recombinant humanized $\mathrm{mAB}-\mathrm{E} 25$, an anti-lgE mAB, in birch pollen-induced seasonal allergic rhinitis. J Allergy Clin Immunol 106: 253-259.

12. Ayres JG, Higgins B, Chilvers ER, Ayre G, Blogg M, et al. (2004) Efficacy and tolerability of anti-immunoglobulin $E$ therapy with omalizumab in patients with poorly controlled (moderate-to-severe) allergic asthma. Allergy 59: 701-708.
13. Vignola AM, Humbert M, Bousquet J, Boulet LP, Hedgecock S, et al. (2004) Efficacy and tolerability of anti-immunoglobulin $\mathrm{E}$ therapy with omalizumab in patients with concomitant allergic asthma and persistent allergic rhinitis: SOLAR. Allergy 59: 709-717.

14. Holgate ST, Chuchalin AG, Hebert J, Lotvall J, Persson GB, et al. (2004) Efficacy and safety of a recombinant anti-immunoglobulin $E$ antibody (omalizumab) in severe allergic asthma. Clin Exp Allergy 34: 632-638.

15. Humbert M, Beasley R, Ayres J, Slavin R, Hebert J, et al. (2005) Benefits of omalizumab as add-on therapy in patients with severe persistent asthma who are inadequately controlled despite best available therapy (GINA 2002 step 4 treatment): INNOVATE. Allergy 60: 309-316.

16. Bousquet J, Cabrera P, Berkman N, Buhl R, Holgate S, et al. (2005) The effect of treatment with omalizumab, an anti-lgE antibody, on asthma exacerbations and emergency medical visits in patients with severe persistent asthma. Allergy 60: 302-308.

17. Slavin RG, Ferioli C, Tannenbaum SJ, Martin C, Blogg M, et al. (2009) Asthma symptoms re-emergence after omalizumab withdrawal correlates well with increasing IgE and decreasing pharmacokinetic concentrations. J Allergy Clin Immunol 123: 107-113.

18. Hayashi N, Tsukamoto Y, Sallas WM, Lowe PJ (2007) A mechanism-based binding model for the population pharmacokinetics and pharmacodynamics of omalizumab. Br J Clin Pharmacol 63: 548-561.

19. Meno-Tetang GM, Lowe PJ (2005) On the prediction of the human response: a recycled mechanistic pharmacokinetic/pharmacodynamic approach. Basic Clin Pharmacol Toxicol 96: 182-192.

20. European Medicines Agency (2010) Guideline on the investigation of bioequivalence.

21. Fox JA, Hotaling TE, Struble C, Ruppel J, Bates DJ, et al. (1996) Tissue distribution and complex formation with $\lg$ E of an anti-lgE antibody after intravenous administration in cynomolgus monkeys. J Pharmacol Exp Ther 279: $1000-1008$

22. Lobo ED, Hansen RJ, Balthasar JP (2004) Antibody pharmacokinetics and pharmacodynamics. J Pharm Sci 93: 2645-2668.

23. Casale TB, Condemi J, LaForce C, Nayak A, Rowe M, et al. (2001) Effect of omalizumab on symptoms of seasonal allergic rhinitis: a randomized controlled trial. JAMA 286: 2956-2967. 